\title{
STRUKTUR LATIHAN SURYA NAMASKARA DALAM MENCAPAI KESEHATAN DIRI
}

Oleh:

\author{
Ni Ketut Pande Muliartini
}

Praktisi Yoga Asana

Email: widhyaputry18@gmail.com

\begin{abstract}
:
Asana is different from physical exercise which gives a burden to muscles but is an exercise that pays attention to relaxation and concentration. In this way, the endocrine glands, internal organs and muscles can also be used to perform their functions. Asana has physical and psychological influences that are useful in the recovery of various diseases. The path of assana sadhana is a step in the eight stages of the Patanjali yoga sutra which is to make our body steady and firm for higher techniques before going to the level of pratyāhara. It turns out that asanas are not only popular among Hindus, many are favored by other people, this proves that by doing äsana in daily life, the asanas are very beneficial for health life both physical, mental, muscular and social health. Yoga teaches calm in dealing with problems or conflicts that occur between individuals. Yoga is an implementation of ethics in philosophy. Yoga can answer the problem of what causes human happiness. Yoga can be used as an alternative treatment, usually done with breathing exercises, asanas poses and meditation.
\end{abstract}

Keywords: yoga, surya namaskara, personal health

\begin{abstract}
Abstrak:
Asana bebeda dengan latihan fisik yang memberikan beban pada otot tetapi asana merupakan latihan yang memperhatikan relaksasi dan konsentrasi. Dengan cara ini, kelenjar-kelenjar endokrin, organ tubuh bagian dalam dan otot-ototjuga didorong untukmelakukan fungsiny a sebagaimana mestinya. Sehingga asana memiliki pengaruh fisik dan kejiwaan yang berguna dalam penyembuhan berbagai penyakit. Jalan sadhana āsana merupakan langkah ketiga dalam delapan tahapan jalan yoga sutra Patanjali yang tujuannya adalah untuk membuat tubuh kita mantap dan teguh bagi teknik-teknik yang lebih tinggi sebelum ke tingkatan pratyāhara. Ternyata kegiatan spiritual āsana bukan saja digemari dikalangan Hindu, melainkan banyak pula digemari oleh kaum umat lainnya, hal ini membuktikan bahwa dengan melakukan äsana dalam keseharian, maka asana sangat bermanfaat bagi kehidupan kesehatan baik kesehatan fisik, mental, otot, dan kesehatan sosial. Yoga mengajarkan ketenangan dalam menyikapi permasalahan atau konflik yang terjadi antara individu. Yoga merupakan implementasi dari etika dalam filsafat. Yoga dapat menjawab permasalahan tentang apa yang menyebabkan kebahagiaan manusia. Yoga dapat digunakan sebagai salah satu pengobatan alternatif, biasanya hal ini dilakukan dengan latihan pernapasan, pose asanas dan meditasi.
\end{abstract}

Kata kunci: yoga, surya namaskara, kesehatan diri

\section{PENDAHULUAN}

Yoga berasal dari bahasa Sansekerta yang berarti " Penyatuan " yang bermakna "Penyatuan dengan sang pencipta " kini yoga telah tersebar di seluruh dunia, yoga telah berkembang secara luas dan universal dengan menyentuh hampir seluruh lapisan masyarakat di dunia. Ajaran yoga di bangun oleh Maharsi Patanjali dan merupakan ajaran yang sangat populer di kalangan umat Hindu. Ajaran yoga merupakan ilmu yang sifatnya praktis dari ajaran Kitab Suci Veda. Maharsi Patanjali mengartikan yoga sebagai Citta vrtti niroddha yaitu pengendalian menuju pengehentian gerak pikiran. 
Pengertian yoga adalah suatu kumpulan praktek - praktek latihan rohani kuno yang pertama kali dilakukan di India. Yoga dibagi menjadi empat, yaitu: Karma yoga, Bhakti yoga, Jnana yoga dan Raja yoga. Yoga menyelaraskan tubuh fisik, pikiran dan jiwa. Yoga adalah metode pengembangan pribadi yang menyelaraskan tubuh, pikiran, dan jiwa dengan cara olah tubuh, aliran pernapasan, dan meditasi di sertai dengan gerak anggota badan. Ajaran yoga sudah dikenal oleh masyarakat India jauh sebelum datangnya bangsa Arya. Para Yogi (praktisi yoga) sudah terdapat di India jauh sebelum jaman Veda.

Yoga berarti pengalaman dari keutuhan atau kesatuan dengan keberadaan bathin. Kesatuan ini hadir setelah menghancurkan dualitas pikiran ke dalam kesadaran tertinggi (Sena, 2018:1). Yoga menitik beratkan pada aktivitas pikiran di mana seseorang memusatkan seluruh pikiran untuk mengontrol dasa indra (sepuluh indra) dan tubuhnya secara keseluruhan.

Salah satu kegiatan yang dipandang mampu memberi berbagai manfaat yang berhubungan dengan kesehatan fisik, mental bahkan kesehatan spiritual dalam yoga adalah Surya Namaskar. Gerakan yoga Surya Namaskar merupakan gerakan yoga yang sangat sederhana tetapi sarat manfaat terutama dalam bidang kesehatan fisik, mental dan spiritual. Dalam bagian pembahasan, penulis akan menguraikan beberapa pokok bahasan yang merupakan dasar pemikiran penulisan artikel ini, diantaranya; (1) Yoga Surya Namaskar dan (2) Manfaat Yoga Surya Namaskar. Tujuan dari pembahasan ini adalah untuk memberikan suatu gambaran yang jelas mengenai bagaimana Yoga Surya Namaskar mampu memberikan manfaat kesehatan fisik, mental dan spiritual dalam menyehatkan kesehatan diri.

\section{PEMBAHASAN}

\subsection{Surya Namaskara}

Yoga adalah sebuah ilmu pengetahuan kuno yang berakar dari filosofi Hindu dan bersifat pantheisme (kepercayaan bahwa seluruh alam semesta dan isinya bersifat ilahi). Ilmu ini sangat kompleks dan membicarakan banyak aspek dari manusia, mulai dari tataran fisikal hingga ke tataran spiritual. Praktisi yoga (kerap disebut yogi) diharapkan menggapai pencerahan paripurna (Brahman) yaitu pengetahuan manusia akan hakekat dirinya yang sejati dimana dia menyadari dan menghidupi dirinya sebagai bagian dari continuum semesta. Ketika seorang manusia telah hidup pada tataran spiritual maka ia disebut telah mencapai Brahman dan telah mencapaii pencerahan paripurna atau Enlightenment (Purwasandi, 2015).

Menurut Patanjali ada delapan tahap dalam cara melakukan yoga yang disebut dengan astangga yoga yaitu dengan Yama ( pengendalian ), Nyama (peraturan- peraturan), Asana (sikap tubuh), Pranayama (latihan pernafasan), Pratyahara (penarikan semua indera), Dharana (memusatkan diri dengan Tuhan) dan Samadhi (menyatu dengan Tuhan).

Astangga yoga merupakan tahapan latihan yang diawali dengan latihan moral melalui latihan Yama dan Niyama, kemudian latihan fisik melalui latihan Asana dan Pranayama, yang di lanjutkan dengan latihan mental melalui latihan Prathyhara dan Dharana, kemudian latihan spiritual berupa Dhyana demi mencapai tujuan akhir yaitu Samadhi atau mencapai realisasi diri.

Secara harfiah Surya Namaskara di artikan sebagai penghormatan kepada dewa matahari sebagai sumber energi kehidupan. Urutan gerakan dan pose dapat di praktekkan pada berbagai tingkat kesadaran yang mencakup asana, pranayama, mantra dan chakra meditasi. Ada total 8 postur yang berbeda dalam urutan 12 perubahan postur Surya Namaskara. Beberapa asana ada yang di ulang dua kali dalam siklus yang sama dari Surya Namaskara dan dalam satu putaran penuh terdiri dari dua kali putaran seri ini. Bedanya, selama seri kedua, praktisi memindahkan kaki berlawanan dari 
yang terlibat dalam gerakan selama seri pertama. Jadi praktisi yoga akan melaksanakan 24 gerakan dalam satu putaran penuh/satu. Gerakan-gerakan tersebut dapat dilihat pada gambar berikut ini;

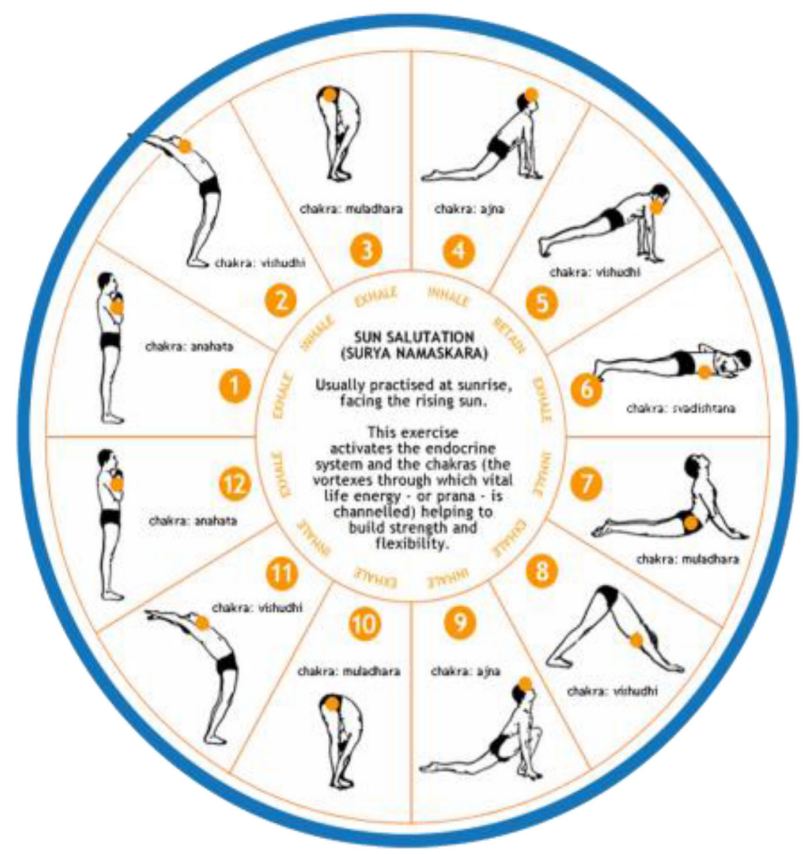

Gambar 1.Gerakan Yoga Surya Namaskar Diakses pada 17 Nopember 2018

https://www.templepurohit.com/significance-andbenefits-of-surya-namaskar

Sebelum memulai seri gerakan yoga Surya Namaskara, praktisi berada dalam posisi yang disebut dengan Yoga Tadasana dimana posisi tubuh berdiri di ujung matras dengan kaki rapat, tubuh lurus, dan kedua tangan diletakkan di sisi tubuh dengan rileks (Budi, 2015). Kedua sisi tubuh diseimbangkan dan berat tubuh distribusikan dengan rata ke kedua telapak kaki.Pernafasan dilakukan dengan pelan dan mantap. Kemudian gerakan dilakukan dengan 12 gerakan inti yaitu:

\section{Pranamasana/Anjali Mudra}

Kedua bahu rileks, kedua tangan diangkat sambil menarik nafas, kemudian kedua tangan dicakupkan di depan dada sambil menghembuskan nafas. Kemudian kedua telapak tangan ditekan dengan lembut sambil mengucapkan doa; "Om mitra ya namah"yang berarti sebuah penghormatan untuk semua mahluk.
Posisi ini melambangkan sikap penghormatan kepada sumber segala kehidupan yaitu matahari yang tak henti-henti memberikan sinar, panas dan energi untuk mendukung kehidupan jagat raya ini. Manfaatnya: Membentuk suatu kedaaan konsentrasi dan ketenangan dalam persiapan untuk latihan yang dilakukan.

\section{Hastauttanasana}

Tangan diangkat dan diregangkan diatas kepala sambil menarik nafas dengan telapak tangan menghadap keatas. Punggung dilengkungkan sekuat-kuatnya ke belakang sehingga terjadi peregangan diseluruh tubuh. Kepala diregangkan kebagian belakang sambil tetap menjaga kelengkungan punggung bagian atas. Pose ini bertujuan untuk peregangan tubuh mulai dari tungkai hingga ujung jari tangan, sambil mengucapkan mantra: "Om ravaye namah" yang berarti penghormatan pada yang bersinar.

Pada posisi ke-2 ini, seluruh tubuh dihadapkan keatas menuju sumber sinar untuk menerima berkahnya. Manfaatnya : Meregangkan isi rongga perut, menghilangkan kelebihan lemak dan memperbaiki pencernaan.

\section{Hasta Padasana}

Nafas dihembuskan sambil melipat tubuh kearah depan dengan menjaga tulang punggung tetap lurus. Telapak tangan dibawa kedepan dan diletakkan di lantai dekat dengan kedua kaki dan posisi kepala sedekat mungkin dengan lutut. Kaki diusahakan tetap lurus, tapi jika hal tersebut sulit dilakukan, lutut bisa ditekuk dulu untuk membantu meletakkan tangan dilantai lalu dilanjutkan dengan gerakan meluruskan lutut dengan lembut. Bagian punggung dipertahankan tetap lurus dengan memfokuskan kesadaran pada panggul sebagai titik sumbu, sambil mengucapkan mantra; “Om suryaya namah" yang berarti penghormatan pada yang menyebabkan segala aktivitas. Manfaatnya : melenyapkan / mencegah sakit perut, megurangi kelebihan lemak pada daerah perut, memperbaiki pencernaan, membantu menghilangkan sembelit, 
memperbaiki peredaran darah ,membuat tulang belakang lemas dan menyelaraskan saraf-saraf tulang belakang.

\section{Asva Sancalanasana}

Lutut kiri ditekuk sambil menarik kaki kanan sejauh mungkin kebelakang, jempol kaki dan lutut diusahakan menyentuh lantai.Pastikan telapak kaki kiri sejajar dengan kedua telapak tangan. Panggul dicondongkan ke depan tulang belakang dilengkungkan sambil tengadah sambil menarik nafas. Konsentrasi dipusatkan pada dahi diantara kedua alis mata. Peregangan akan terasa dari paha ke bagian atas tubuh sampai pada diantara kedua alis, kemudian ucapkan doa; "Om bhanave namah" yang berarti penghormatan pada yang menyinari, agar kegelapan yang ada dalam diri berakhir. Manfaatnya : Memijat organ perut dan memperbaiki fungsinya, memperkuat otot-otot kaki, menyeimbangkan urat saraf.

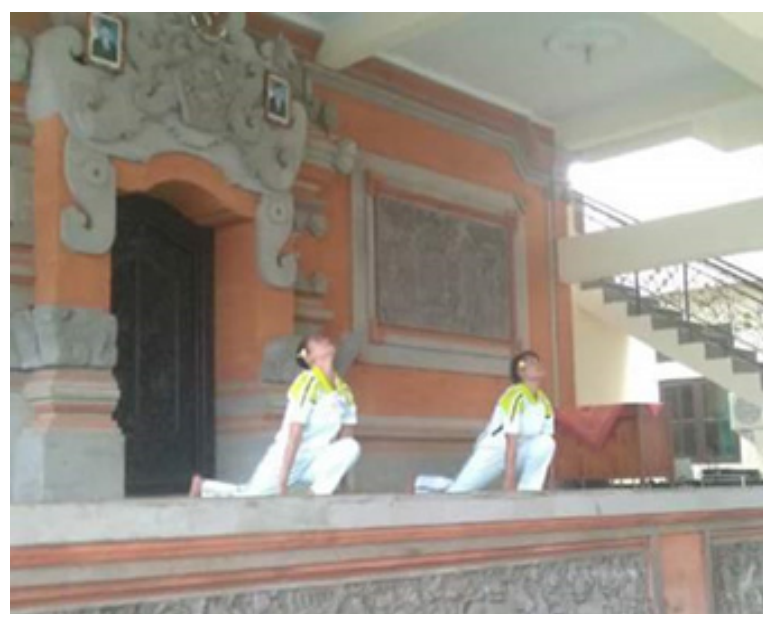

Gambar 2. Gerakan Asvasancalanasana Dokumen pribadi

\section{Parvatasana}

Pada posisi ini kaki kiri dipindahkan ke belakang berdampingan dengan kaki kanan. Pantat/tulang ekor ditarik perlahan-lahan keatas sambil merendahkan posisi kepala sehingga berada diantara lengan, shingga tubuh membentuk segitiga dengan lantai.Gerakan ini dilakukan sambil menghembuskan nafas.Tumit menyentuh lantai dan kepala dibungkukkan hingga mampu melihat lutut.Tulang belakang dipertahankan lurus. Peregangan pada bagian kaki akan maksimal jika seluruh telapak kaki menyentuh lantai. Kesadaran difokuskan pada leher sambil mengucapkan mantra; "Om khagaya namah" yang berarti penghormatan pada yang bergerak melintasi langit.Pada posisi Parvatasana kita memberi hormat pada pengukuran waktu dan memohon kemajuan hidup.

Dalam rangkaian gerakan Adho Mukha Svanasana, setelah Parvatasana, gerakan dilanjutkan dengan Khumbakasana yaitu gerakan meluruskan lengan seperti gerakan awal push up, sambil menarik nafas dan pandangan lurus ke bawah. Gerakan selanjutnya adalah Chaturanga Dandasana yaitu gerakan menekuk siku 90 derajat hingga seluruh tubuh lurus sejajar dengan lantai sambil menghembuskan nafas. Manfaatnya: Menguatkan saraf dan otot pada kedua lengan dan kaki, meleturkan tulang belakang pada arah yang berlawanan menuju sikap sebelumnya, memberikan saraf aliran darah yang tersumbat.

\section{Ashtanga Namaskara}

Lutut ditekuk hingga menyentuh lantai sehingga secara bersamaan dada dan dagu menyentuh lantai juga, tetapi pantat dipertahankan tetap diatas.Tulang belakang dilengkungkan pandangan kedepan.Kesadaran dipusatkan pada pusat tubuh/otot punggung sambil mengucap dalam hati; "Om pusne namah" yang berarti penghormatan pada pemberikekuatan dan makanan.Pada posisi ini kita menyentuhkan 8 sudut tubuh (dagu, dada, tangan kanan, tangan kiri, lutut kanan, lutut kiri dan kedua punggung kaki) dengan tujuan mempersembahkan seluruh keberadaan diri kita dengan harapat untuk mendapatkan anugrah kekuatan fisik, mental dan spiritual dari Matahari. Manfaatnya :Menguatkan otot-otot kaki dan lengan, memperkuat dada

\section{Bhujangasana}

Pada pose ini, badan diluncurkan kedepan 
sambil mengangkat posisi dada sembari menurunkan pinggul, semua bertumpu pada lengan hingga pandangan mata ke atas. Kaki dan perut bagian bawah diusahakan tetap menempel di lantai. Kesadaran dipusatkan ke dasar tulang belakang, rasakan ketegangan dari penatikan tubuh bagian depan dan tekanan paha ke lantai sambil mengucap dalam hati; "Om hiranya garbhaya namah" yang berarti penghormatan pada sang diri kosmis keemasan. Posisi ini adalah penghormatan pada Matahari untuk memohon pembangkitan kreativitas. Manfaatnya: menghilangkan berbagai penyakit perut, melatih tulang belakang, melemaskan otot lengan, memberikan kekuatan kembali pada saraf-saraf tulang belakang.

\section{Adho Mukha Svanasana atau Parvatasana}

Kembali ke gerakan ke 5, tetapi kali ini mantra yang diucapkan dalam hati adalah; "Om maricaya namah" yang berarti penghormatan pada sinar matahari. Pada posisi ini diyakini untuk memohon kekuatan pembeda agar dapat membedakan antara yang nyata dan yang tidak nyata. Manfaatnya: Menguatkan saraf dan otot pada kedua lengan dan kaki, meleturkan tulang belakang pada arah yang berlawanan menuju sikap sebelumnya, memberikan saraf aliran darah yang tersumbat.

\section{Asva Sancalanasana}

Kembali ke posisi 4, tetapi kali ini kaki kanan yang ditarik kedepan sambil menarik nafas. Mantra yang diucapkan dalam hati; "Om adityaya namah" yang berarti penghormatan pada putra Aditi dengan tujuan untuk penghormatan pada Ibu kosmis tidak terbatas. Manfaatnya : Memijat organ perut dan memperbaiki fungsinya, memperkuat otot-otot kaki, menyeimbangkan urat saraf.

\section{Hasta Padasana}

Kembali ke posisi 3, sambil menghembuskan nafas dan mengucap dalam hati; "Om savitre namah" yang berarti penghormatan pada kekuatan pendorong dari matahari atau kekuatan kehidupan. Manfaatnya : melenyapkan / mencegah sakit perut, megurangi kelebihan lemak pada daerah perut, memperbaiki pencernaan, membantu menghilangkan sembelit, memperbaiki peredaran darah, membuat tulang belakang fleksibel dan menyelaraskan saraf-saraf tulang belakang.

\section{Hastauttanasana}

Kembali ke posisi 2, sambil menarik nafas dan mengucap dalam hati; "Om arkaya namah" yang berarti penghormatan pada yang layak dipuja yaitu sang pemberi energy dan sumber kehidupan. Manfaatnya : Meregangkan isi rongga perut, menghilangkan kelebihan lemak dan memperbaiki pencernaan.

\section{Pranamasana/Anjali Mudra}

Kembali ke posisi 1, sambil menghembuskan nafas dan mengucap dalam hati; "Om bhaskaraya namah" yang berarti penghormatan pada matahari yang menghantarkan pada pencerahan sehingga umat manusia dituntun menuju ke jalan tersebut. Manfaatnya: Membentuk suatu kedaaan konsentrasi dan ketenangan dalam persiapan untuk latihan yang dilakukan

Setelah ke 12 gerakan tersebut dilaksanakan dua set, praktisi akan kembali ke posisi Yoga Tadasana. Kemudian gerakan akan diakhiri dengan posisi yang disebut dengan Savasana, yaitu pose relaksasi dimana tubuh berada dalam posisi terlentang, tangan diletakkan lurus disisi badan. Posisi ini dikenal dengn "pose mayat" dimana seluruh tubuh secara sadar direlaksasi untuk merasa santai sampai terasa lemas seakan tak bernyawa, yang bertujuan untuk menenangkan pikiran, menurunkan tingkat stress dan membuat tubuh menjadi lebih rileks. Gerakan yoga Surya Namaskar tersebut adalah pose yoga sangat aman untuk dilakukan karena jika satu set dilakukan dengan benar hal tersebut akan memberikan manfaat yang sangat baik bagi kesehatan tubuh dan mental serta tidak akan menyebabkan ketegangan atau cidera. Oleh karena itu, gerakan yoga ini sangat cocok untuk dipraktekkan kepada pemula yang baru mulai belajar yoga. 


\subsection{Manfaat Mempraktekkan Surya Namaskar}

Surya Namaskar merupakan serangkaian latihan holistik yang bukan hanya memberikan manfaat kesehatan fisik, tetapi juga mental serta manfaat spiritual. Surya Namaskar mampu memberikan semua manfaat kesehatan utama dari yoga dalam seri gerakan yang sangat ringkas. Keuntungan dengan melakukan gerakan surya namaskar adalah latihan fisik untuk untuk otot, sendi, ligamen dan sistem kerangka dengan meningkatkan postur, fleksibilitas dan keseimbangan. Disamping itu, gerakan ini juga merangsang seluruh sistem pada tubuh secara fisiologis. Yoga surya namaskar mampu memberikan integrasi antara fisik dan mental yang berguna bagi fleksibilitas dan ketahanan tubuh bagian atas. Hal ini baik untuk jantung, merangsang sistem kardiovaskular, meningkatkan kadar oksigen dalam darah dan membantu memperkuat jantung. surya namaskar baik untuk sistem pencernaan dan sistem saraf. Ini merangsang sistem limfatik dan mendukung kesehatan sistem pernapasan atau kerja paru-paru.

Seperti kebanyakan bentuk latihan yoga, surya namaskar juga memberikan manfaat mental bagi praktisinya. Seseorang akan merasakan suatu keadaan keadaan santai, perasaan yang ceria, penurunan ketegangan, pelepasan stres dan kecemasan saat melakukan surya namaskar.

Gerakan Yoga surya namaskar mampu meningkatkan ketajaman fokus, percaya diri, dan kedisiplinan, mudah untuk berkonsentrasi, dan belajar untuk mencapai pose yang sangat menenangkan. Oleh karena itu, segala jenis tekanan yang terjadi pada seseorang bisa diatasi dengan meningkatkan stabilitas/keseimbangan mental.

Jadi, yoga dapat memberikan manfaat spiritual yang luas bagi seorang praktisi, seperti; (1) Yoga dapat membantu seseorang untuk memperdalam hubungannya dengan alam yang ada disekitarnya (2) Yoga mengajarkan seseorang mengenali dirinya sebagai mahluk ciptaan Tuhan sehingga mereka mampu menyadari pentingnya kesehatan, dan, (3) Yoga mengajarkan untuk berkonsentrasi dan mencapai kedamaian untuk menghilangkan stress.

\section{PENUTUP}

Yoga banyak sekali manfaatnya bagi tubuh manusia apabila benar cara pelaksanaannya dan dilakukan secara rutin. Melalui latihan surya namaskara kelenjar organ akan memperoleh pemijatan sehingga tubuh bekerja dengan harmonis dan sehat selain itu surya namaskar mampu memberikan manfaat yang sangat luas mulai dari meningkatkan ketahanan fisik hingga meningkatkan stabilitas mental. yoga dapat memberikan manfaat spiritual yang luas bagi seorang praktisi, seperti; (1) Yoga dapat membantu seseorang untuk memperdalam hubungannya dengan alam yang ada disekitarnya (2) Yoga mengajarkan seseorang mengenali dirinya sebagai mahluk ciptaan Tuhan sehingga mereka mampu menyadari pentingnya kesehatan, dan, (3) Yoga mengajarkan untuk berkonsentrasi dan mencapai kedamaian untuk menghilangkan stress.

Yoga dapat memberikan manfaat yang sangat luas bagi kesehatan fisik, mental dan spiritual bagi seorang praktisi. Untuk itu pemahaman ajaran yang tepat serta mempraktekkan dengan benar disertai guru penuntun dari ajaran Surya Namaskar tentunya diperlukan dalam mengembangkan esensi yoga pada umumnya dan esensi diri pada khususnya.

\section{DAFTAR PUSTAKA}

Budi, Cakepane Gamabali. 2015. Yoga Surya Namaskara. Online Article diakses pada 16 Nopember 2018 dari http://cakepane.blogspot. co.id/2015/01/yoga-surya-namaskara.html

Kamajaya, Gede. 1998. Yoga Kundalini. Surabaya: Paramita.

Purwasandi, Devi. 2015. Yoga. Dalam: https://devipurwasandi.wordpress.com. Diunduh 
tanggal 19 Nopember 2018.

Sena, I Gusti Made Widya. 2018. Kinesiologi Yoga Asanas (Kunci Kebahagiaan Tubuh, Pikiran dan Jiwa), Jurnal Yoga dan Kesehatan, 1(1), 1521.

Svāmī Satyānanda Sarasvatī. 2002. Āsana Prāṇāyāma Mudrā Bandha. Surabaya: Paramita

Yudhiantara. 2006. Menyikapi Rahasia Yoga. Surabaya: Paramita 